\title{
DEFINIÇÃO DO CONCEITO DE PROPRIEDADE IMOBILIÁRIA NA DOUTRINA E NO SISTEMA JURÍDICO CONSTITUCIONAL - CÍVEL POSITIVADO BRASILEIRO E INTERNACIONAL: ARTIGO 1.225, INCISO I, DA LEI 10.406 DE 10 DE JANEIRO DE 2002 INSTITUINTE DO CÓDIGO CIVIL BRASILEIRO
}

\section{ARTIGO ORIGINAL}

COSTA, Josécley Dos Santos ${ }^{1}$

COSTA, Josécley Dos Santos. Definição do conceito de Propriedade Imobiliária na Doutrina e no Sistema Jurídico Constitucional - Cível positivado brasileiro e internacional: Artigo 1.225, Inciso I, da Lei 10.406 de 10 de janeiro de 2002 instituinte do Código Civil Brasileiro. Revista Científica Multidisciplinar Núcleo do Conhecimento. Ano 05, Ed. 12, Vol. 08, pp. 24-42. Dezembro de 2020. ISSN: 24480959, Link de acesso: https://www.nucleodoconhecimento.com.br/lei/propriedadeimobiliaria

\section{RESUMO}

O oferecimento deste ofício tem como objetivo definir o conceito da propriedade imobiliária. Traçando um panorama geral evolutivo histórico, desde à pré-história até os dias contemporâneos, referente ao Direito Real, em uma escala global, relacionando as razões históricas, dos sistemas sociais e econômicos ao tocante da propriedade imobiliária, que conduziu o seu aparecimento e desenvolvimento até os conglomerados que instituíram as cidades. Inclusive a criação do seu conceito em caráter nacional e internacional, ordenado por sistemas de governos em seus regimes governamentais, com enfoque interdisciplinar, fornecendo não somente de base, mais

\footnotetext{
${ }^{1}$ Mestrando em Direito pela Fundação Universitária Iberoamericana, (MBA) em Direito Imobiliário pela Laureate International Universities, complexo (FMU). Bacharel em Direito pela Faculdade Regional da Bahia, (Unirb).
} 
também de compreensão dos fatores da indústria da construção civil, motriz do vetor econômico dos vagões das pequenas economias, das propriedades públicas e privadas através do cotidiano, visualizando a trajetória da observação de um pesquisador até o resultado deste trabalho, do qual foi conduzido em uma sequência lógica. A metodologia se pautou na pesquisa bibliográfica, numa abordagem sobre 0 problema, usando-se dos métodos: indutivo, procedimento histórico, com o da observação da vida real, correspondendo a delimitação do tema, conduzindo para um caminho específico, ou seja, definir o conceito da propriedade imobiliária. Indo das constatações mais particulares, às leis e teorias doutrinárias, numa comunicação ascendente. A indagação e o problema deste trabalho residem na pergunta: o que é a propriedade imobiliária? Vale elucidar, o direito do proprietário e sua faculdade, presente no Código Civil Brasileiro vigente. A origem da propriedade imobiliária na história surge na Idade Antiga, na Idade Média surge a faculdade do proprietário, dentre outros surgimentos, a exemplo: do condomínio, da dicotomia: terras públicas e privadas, da posse, da nomenclatura: Direito Real, etc. Em várias Constituições, Códigos e Legislações Internacionais, não se encontrou a definição deste conceito.

Palavras-chave: Propriedade Imobiliária, Direito Brasileiro, internacional.

\section{INTRODUÇÃO}

O presente trabalho visa definir o conceito da propriedade imobiliária, que consuetudinariamente é o mais vasto direito da humanidade em relação aos direitos subjetivos patrimoniais. Tornando-se um Direito Real por primazia em torno do âmbito em todos os Direitos das Coisas do Código Civil brasileiro, seguindo-se como um direito fundamental, essencial e indispensável, presente no artigo 17 da Declaração dos Direitos do Homem e do Cidadão, conforme o qual toda pessoa humana têm o direito de ter a sua propriedade imobiliária, a sua residência, onde possa domiciliar-se com a sua família em concórdia com a liberdade, a paz, a vida e a segurança que o lar abarca entre as pessoas. A propriedade imobiliária, ou seja, a propriedade privada, está exposta e inaugurada no caput do artigo $5^{\circ}$ da Carta Magna de 1988, assegurada e expressa no inciso XXII. A propriedade imobiliária é princípio da ordem econômica 
como determina o inciso II do artigo 170 da Constituição Federal do Brasil de 1988 (GUERRA, 2011).

É um direito que, por si só, não salvaguarda as liberdades e a autonomia dos direitos civis, para tornar certo e infalível, ratificando este eficaz instrumento, que cria um círculo autônomo com o proprietário por recíproca vênia do Estado, sem ser afligido por infrações da sociedade, se faz necessário que o titular cumpra a função social da propriedade imobiliária, mas no entanto, este nobre direito não tem até ontem um conceito que o defina.

Em Roma o imperador Justiniano se aproxima da definição do conceito da propriedade imobiliária, definindo o conceito do direito de proprietário, do qual o Direito Civil brasileiro toma como base. O Código Civil brasileiro, feito pelo Professor Miguel Reale, segue o mesmo entendimento do direito romano, data vênia não define o conceito da propriedade imobiliária, objetivo deste Artigo Técnico Científico.

E, por conta de ser um tema inédito, será a ocupação deste Trabalho de Conclusão de Curso da Pós-Graduação, (MBA) em Direito Imobiliário. Para dar conta desta investigação metodológica, a metodologia aplicada a este estudo, se pautou na pesquisa bibliográfica, numa abordagem mais ampla sobre o problema, usando-se do método indutivo, aproximando os fenômenos e conduzindo para um caminho específico, ou seja, definir o conceito da propriedade imobiliária.

Indo das constatações mais particulares, às leis e teorias doutrinárias, numa comunicação ascendente, usando o método do procedimento histórico juntamente com o da observação da vida real, correspondendo a delimitação do tema, qual seja, vale dizer, a Definição do Conceito de Propriedade Imobiliária, inerente artigo 1.225, inciso I, da Lei 10.406 de 10 de Janeiro de 2002, Instituinte do Código Civil brasileiro.

Teoricamente, este estudo se apoiou principalmente no direito romano, em Leis alienígenas e principalmente nos mestres e juristas do Direito Real Ocidental, Professor Orlando Gomes, Professor Miguel Reale, Imperador Justiniano, Karl Marx e Proudhon, ao tratar do Direito Real no tocante à propriedade imobiliária. 
O Direito das Coisas traz o Direito Real, que por sua vez é aquele responsável pela relação jurídica de uma pessoa a um bem material ou imaterial, é um direito de um titular que recai sobre a coisa. O artigo 1.225 do Código Civil brasileiro de 2002, traz um rol taxativo sobre o Direito Real, trataremos em especial da propriedade, inerente ao inciso I, quer seja, a propriedade imobiliária.

O direito de propriedade da propriedade imobiliária, vale elucidar, o direito do proprietário, se dá segundo o artigo 1.227 do Código Civil brasileiro vigente, do qual diz que: "Os direitos reais sobre imóveis constituídos, ou transmitidos por atos entre vivos, só se adquirem com o registro no Cartório de Registro de Imóveis dos referidos títulos (Arts. 1.245 a 1.247), salvo os casos expressos neste Código", (VADE, 2002).

O artigo 1.228 do mesmo código traz à faculdade do proprietário sobre a propriedade imobiliária quando diz que: "O proprietário tem a faculdade de usar, gozar e dispor da coisa, e o direito de reavê-la do poder de quem quer que injustamente a possua ou detenha", (VADE, 2002).

Trataremos especificamente no afã de definir o conceito da propriedade imobiliária, por conta de o Código Civil brasileiro ter ocultado o conceito, por entender através da metafísica quântica que ninguém cria nada ao menos descobrir pela investigação científica, ensinada por René Descartes.

O Código Civil somente informa a condição de aquisição da propriedade imobiliária e a faculdade do proprietário, quando tratamos de Direito Real. Em determinado momento ao tratar sobre o direito de propriedade da propriedade imobiliária, seria de grande valia para a comunidade científica, o entendimento, por ser um direito fundamental e humano, a definição deste conceito é de suma importância ao se indagar, o que é a propriedade imobiliária?

Dependendo da necessidade interpretativa, és que o legislador pátrio não a explicitou, destarte, este trabalho se ocupará em trazer à baila no campo doutrinário e legal o devido e tanto esperado conceito, de forma atual e moderna. O trabalho será dividido em três etapas a primeira trará uma informação de forma geral, no discorrer da 
segunda etapa se iniciará por uma abordagem histórica evolutiva da propriedade imobiliária, partindo da origem até os dias atuais, tratando em cada idade à evolução deste direito em face da humanidade, e pôr fim a conclusão do conceito da propriedade imobiliária, com um prisma constitucionalista e civilista, incumbência deste trabalho.

\section{EVOLUÇÃO HISTÓRICA}

Através de um raciocínio darwiniano, no início da humanidade, quando o homem préhistórico habitava a terra, não existia a noção de propriedade, quão mais de propriedade imobiliária. Estes viviam de forma nômade em pequenos grupos familiares, coletores de frutas e caçadores de animais, não estabeleciam territórios. Passados determinado tempo, grupos de famílias tornaram-se clãs, estes começaram a povoar e fixar-se em territórios demarcando-os, desta forma iniciaram-se as primeiras cidades antigas. No território da Europa surgiram as primeiras CidadesEstados, a exemplo: Esparta, Celta, Grécia, Atenas e Roma; no Oriente Médio: a Mesopotâmia, Israel, Síria e Babilônia, África e Egito. Assim, dado este requisito, dentre outros, transporta a mudança de idade na história.

A origem da propriedade imobiliária na história da humanidade surge na Idade Antiga, através da posse na sociedade greco e romana, e lhe servia como pilastra por ter conexão com a religião, isto segundo Fustel Coulanges, em sua obra La Cité Antique (A Cidade Antiga). Suas moradias tinham um caráter íntimo e familiar, sempre protegida pelos deuses das cidades, a exemplo a deusa Atena, o Partenon da polis grega, a Cidade-Estado de Atenas. Descrita por Homero, como uma cidade murada que na parte superior era a residência dos deuses, o templo, e na parte inferior as residências dos humanos, quando retrata a Aprocoles, "brota o condomínio urbano". (Grifo nosso). Havia deuses dos lares, um deus doméstico que consagrava a propriedade imobiliária, a casa; um estranho que se ultrapassa o local do altar cometeria grave impiedade, caso não tivesse autorização do chefe de família, (GUERRA, 2011). 
Percebe-se que a relação do direito da propriedade imobiliária dava-se de forma religiosa, não se falava em função social da propriedade, a função da domus tinha um caráter religioso. No período antigo de poucas descobertas, Théos, deus em grego, respondiam as indagações, para os tempos antigos servia como proteção da inviolabilidade do domicílio, ou seja, do lar sobre a proteção divina. Na Idade Antiga era muito comum sincretizar direito e religião, por conta deste fato supra narrado surge a inviolabilidade do domicílio, do qual está presente no inciso XI do artigo $5^{\circ}$ da Carta Política de 1988 do Brasil (Grifo nosso).

Em Roma, os romanos não definiram a propriedade imobiliária. De fato, definiram o direito de propriedade. Vêm à Idade Média, tendo como base rescritos de Leis de imperadores anteriores. Justiniano compila diversas Leis esparsas e cria o primeiro Código Civil da humanidade do mundo ocidental, denominado de Corpus luris Civilis Romani. Constituído de quatro livros: (Institutiones, Codex, Novella e Digesto).

Os juristas romanos extraíram o conceito de Direito de Propriedade, dada pela faculdade do proprietário. "Assim, com base num rescrito de Constantino (C. IV, 35, 21), relativo à gestão de negócios, definiram o proprietário como suae rei moderator er arbiter, (regente e árbitro de sua coisa)." (GUERRA, 2011, p. 30).

O império romano a esta época era detentor de uma vasta extensão territorial, de fato não foi em Roma, mais sim em Constantinopla a pedido do imperador lustinianus Augustus (Justiniano Augusto), no período correspondente a metade do século VI definiram o conceito de proprietário. Outro fragmento do Digesto traduz o direito de possuidor, correspondente ao possuidor de boa-fé, deduziram que a posse seria:

Jus utendi et abutendi, que seria o direito de usar e abusar de sua coisa, e de outra Lei do Digesto em que se define a liberdade, resultou a aplicação desse conceito à propriedade que, então seria: Naturalis in re facultas eius quod cuique facere libet, nisi si quid aut ui aut iure prohibetur, traduzindo: faculdade natural de fazer o que se quiser sobre a coisa, exceto aquilo o que é vedado pela força ou pelo direito, (GUERRA, 2011, p. 30).

Destarte, postas as cidades, circunstancialmente e sucessivamente à face sincrética da relação ao direito junto com a religião, ambos inerente à propriedade, concomitante 
ao proprietário da propriedade imobiliária privada para fins residenciais, anteriormente ao surgimento do comércio e dos centros urbanos o desenvolvimento era praticado na propriedade imobiliária rural, pela à agricultura e a criação de rebanhos de animais.

O conglomerado das propriedades comuns residenciais, após o êxodo rural do declínio feudal, que mais adiante trataremos amiúde, foi o gens, para a formação das primeiras cidades medievais, vale destacar que existiam cidades construídas à idade antiga, à exemplo: Roma, que a esta época contava com distribuição de água através de dutos e saneamento básico. A zona urbana era constituída pela área demarcada onde se situava a sede do governo, enquanto a zona rural era as pequenas frações de terra ao redor desta área central, onde os camponeses viviam em propriedades rurais.

Geralmente era um bem de família, na casa habitavam os membros familiares, agregados e serviçais, era desde aqui inalienável. Neste momento a propriedade era de cunho coletivo, uma espécie de condomínio de fato, por conta do bem pertencer a mais de uma pessoa, daí surge ideia de vários proprietários sobre o mesmo bem, nasce o condomínio (Grifo nosso).

O feudalismo da Idade Média consistia em um sistema fundiário, dada pela exploração das terras rurais dos monarcas, que adquiriram após fortes combates, surge os condomínios residenciais rurais, onde os vassalos construíam suas residências entre os muros do reinado, próximo aos castelos. Um período de grande miséria e violência após o evento da Santa Inquisição, que assolaram as pessoas comuns, das quais perderam suas propriedades, restando na Europa, somente as terras da Igreja e dos reis, daí a terminologia Direito Real (Grifo nosso).

Basicamente os proprietários de terras eram os monarcas e a igreja, uma sociedade que tinha como regime de governo o monárquico absolutista, o poder se concentrava totalmente nas mãos dos monarcas e do clero, uma economia de subsistência agrária, baseada no trabalho servil, onde a terra era concedida pelo senhor feudal ao vassalo, em troca de obrigações. Tratava-se de um sistema político-econômico-social-agrário que vigorou na Europa. 
Os senhores feudais eram os proprietários de grandes extensões de terras, enquanto os trabalhadores eram chamados de servos, era feita uma cerimônia de vassalagem, onde o denominado senhor feudal, passava a posse das terras em troca das produções agrícolas. O sistema feudal obrigava a produção de alimentos através de uma agricultura social do reino, no afã de fomentar a necessidade de subsistência dos habitantes do feudo. Deste modo, germina-se a gênese da função social da propriedade (Grifo nosso).

O território do Feudo era dividido por três partes. A primeira era desmembrada e demarcada, e chamava-se dominium, era a parte da terra reservada exclusivamente ao senhor feudal e trabalhada pelo servo; a segunda terra comum era destinada às matas e aos pastos, das quais poderiam ser usadas por ambos, o senhor e o servo; enquanto a terceira terra do manso servil, que era a parte que correspondiam aos servos, aparece o desmembramento (Grifo nosso).

Por conta dessa exploração de insumos provenientes das terras, surge a propriedade comum pertencente ao grupo de particulares, que pertenciam às famílias, a outra pertencente ao monarca, estas são as duas características da propriedade romana, desta forma a denominada dicotomia: terras públicas e privadas (Grifo nosso).

A Idade Média rejeitou a propriedade exclusiva do Direito Romano e tornou-se marcada pelo sistema feudal, uma economia com base na exploração agrária, a agricultura era a atividade que gerava a riqueza social da época, nas visualizações passadas, ser proprietário de terras, era sinônimo de riqueza.

Dada à exploração dos monarcas sobre a vassalagem, durante determinado período de tempo, em que pelo contrato os camponeses ficavam com a sobra dos excedentes agrícolas, dos quais eram vendidos nas feiras livres medievais. Estes reunidos com seus pecúlios extraídos dos seus labores se rebelaram contra o rei, causando o declínio do sistema feudal, iniciando-se uma nova classe emergente com o epíteto de burguesa. 
Aliada aos iluministas, que refutavam o modelo de governo, à época somado aos resquícios problemáticos das penas de morte do Tribunal da Santa Inquisição, onde os reis junto aos clérigos tiravam as terras e as vidas das pessoas da sociedade europeia medieval, veio a revolta, onde ocasionou posteriormente a Expansão Marítima. Ao período do século (XV ao XVIII), países como: Portugal, Espanha, França e Inglaterra, buscavam a posse de novas terras, inclusive nas Américas. A Europa vivia uma época de epidemias, faltavam mão de obra nos campos, declínio do feudalismo, sobravam guerras e faltava o ouro, o comércio que iniciara há um século atrás, sofreria sua primeira depressão.

\section{PROPRIEDADE IMOBILIÁRIA NO DIREITO BRASILEIRO}

No Brasil colônia tínhamos as capitanias hereditárias, que trazia o mesmo objetivo de produção agrícola importada do sistema feudal, pela coroa portuguesa. A terra era dividida em lotes ou glebas de grandes extensões territoriais, totalidade de terras destinadas à produção agrícola que buscava o melhor aproveitamento do solo, trazendo a mesma função de produção agrícola europeia, onde-se fomentava o mercado europeu com os commodities. Particularmente, tais relatos aludem ao período colonial, quando o Brasil detinha um enorme território livre para ser colonizado, proporcionando incentivo para o desbravamento e para a colonização do interior.

Todavia, esta colonização se deu de forma desorganizada, atinente a repartição do solo referente à costa marítima, adentrando ao interior do território brasileiro, não houve precisão na demarcação da terra, da qual estava a ser explorada pelos europeus, que instituíram o modelo colonial. Concederam gigantescas propriedades imobiliárias ambientais, uma imensa floresta Atlântica foi disponível para o desflorestamento, no afã de transformar em propriedades rurais, hoje urbanas, das quais chegavam ao limítrofe dos estados do Goiás, Mato Grosso, Tocantins e Maranhão, denominado este grande território geográfico de peixe-boi.

Geograficamente, observa-se os recortes de territórios inerentes ao globo terrestre em demarcações geográficas, onde houve conflitos ao longo da história com uma 
demarcação de linhas em curvas, ou seja, não tangentes. Por conta de a posse ter um caráter de dinamismo, dilatava-se e diminuíra-se, embora houvesse a tecnologia geodésica de marcação territorial, a esta época, isto não ocorrerás na llha de Vera Cruz, Brasil. Em outras regiões que não houve conflitos, houve demarcações em linhas tangentes, retas. Um exemplo peculiar é a nação dos Estados Unidos das Américas (EUA), que a costa do Oceano Atlântico, onde chegaram os ingleses houve uma demarcação sutilmente não tangente, em curvas, enquanto o oeste, em direção às margens do Oceano Pacífico, as demarcações são predominantemente em linhas retas, tangentes, podendo afirmar, que são figuras geométricas denominadas de polígonos regulares e irregulares, inseridos em mapas geográficos.

Manifestar-se a Idade Moderna, a Propriedade Imobiliária torna-se um direito fundamental, um instituto jurídico inconcebível ao direito privado, tornando-se um direito civil, inerente ao direito de família e empresarial. Passa-se alguns anos e o direito da propriedade imobiliária integra a ordem econômica e financeira.

O Estado Moderno Democrático de Direito, tem sua fronteira de transição a face do Estado Monárquico Absolutista do século XVIII, e que acarretou modificações nas relações sociais. Historiadores, consideram como marco desta idade a queda da bastilha, concluindo à Revolução Francesa. A Idade Moderna nasce simultaneamente com o lluminismo, e por consequência, rebenta o broto do Estado Democrático Moderno de Direito, preconizado pelos direitos de igualdade, fraternidade e solidariedade, integrando-os o direito de propriedade da propriedade imobiliária privada.

A Projeção imediata na ordem jurídica, juntamente com o individualismo que marcou os códigos civis nos séculos passados. Como reação do lluminismo aos privilégios do sistema feudal, permitia ao indivíduo isolar-se dos demais no uso, gozo e fruição dos seus bens, de modo absoluto e exclusivo. (GUERRA, 2011).

O Direito Romano usava inicialmente o termo dominium e depois proprietas, como poder de uma pessoa sobre seus bens imóveis, estendendo-se aos bens móveis e até as pessoas. Sucessivamente, sobreveio a Idade Contemporânea, aos nossos 
tempos, atual período da história ocidental, trazendo o crescimento desordenado da urbanização, em face do direito da propriedade imobiliária, construindo-se favelas e guetos, construções irregulares, loteamentos clandestinos, falta abastecimento de água e saneamento básico.

Deslizamentos, enchentes, ocupações ilegais, puxadinhos sem base para sustentação, esgoto ao céu aberto, desrespeitos ambientais, em décadas resultaram inúmeros problemas com os quais as populações das cidades brasileiras, até hoje convivem, não se falavam em leis de diretrizes urbanísticas. No entanto, com o constante aumento populacional, a terra foi se tornando cada vez mais rara e onerosa, surgindo a partir de então os problemas sociais a ela relacionados, destacando-se a falta de moradia, os conflitos agrários e a especulação do mercado imobiliário.

No decorrer da história vários foram os entendimentos, mais de fato, primeiro aparece a posse da propriedade imobiliária, o advento de propriedade da propriedade imobiliária, vale dizer para uma melhor elucidação, o direito de propriedade do bem imóvel se apresenta no Estado Novo, quanto este, estar a serviço dos cidadãos, vale dizer o Estado Democrático de Direito. Criando instituições de balcões de informações sobre matrículas de bens imóveis denominados de Cartórios de Registros de Imóveis, pós-burocracia, ofertando segurança jurídica, quando todos sabem que ninguém pode discutir judicialmente com êxito a titularidade do proprietário após o registro da escritura pública, surge de fato, e de direito, a propriedade da propriedade imobiliária (Grifo nosso).

A propriedade nos aproxima do domínio, podendo ser no sentido do que é próprio de alguém, ou alguma coisa é da propriedade de alguma pessoa, podendo ser um bem da qual é distinta de outra propriedade, um imóvel rural ou urbano, um terreno, um prédio, uma casa, um sítio, uma fazenda, etc.

Em termos do século XX, chega-se em 1950, na cidade de São Paulo, de fato a primeira metrópole brasileira. Houve naquela época um grande êxodo rural no Brasil, principalmente de nordestinos, que castigados pela seca, sonhavam com uma vida melhor na terra da garoa, através do trabalho na construção civil. De início o Brasil 
era predominantemente rural, depois vem a ser predominantemente urbano, tendo a maior população em áreas urbanas.

Mais o processo de urbanização se deu de forma desordenada, as leis atuais a exemplo da Lei de n. 10.257/2001, batizada de Estatuto da Cidade, uma Lei nova e genérica, onde traz os requisitos da Política Nacional de Urbanização, onde cidades que tenham sua população acima de vinte (20) mil habitantes fica obrigada por ordem constitucional, com fulcro no caput do Art. 182 e seu $\S 1^{\circ}$ a legislar, criando leis orgânicas na finalidade de trazer à baila territorial diretrizes para o parcelamento do solo. Cidades com população abaixo de vinte (20) mil habitantes não têm obrigações de criar um plano diretor, mais não estão impedidas de criá-los, muito embora a Lei não proibiu, havendo uma presunção de permissão.

\section{PROPRIEDADE IMOBILIÁRIA NO DIREITO INTERNACIONAL}

Em várias Constituições, Códigos Civis e Legislações Internacionais, não se encontrou a definição do conceito da propriedade imobiliária, desta forma seguem-se algumas leis alienígenas, inframencionadas:

Na França, após tomada da Bastilha, a Assembleia Nacional Constituinte francesa passou a elaborar a Constituição. Em paralelo, uma comissão de deputados decidira escrever um preâmbulo com os ideais da revolução. Reunidos estavam: Thomas Jefferson embaixador norte-americano em Paris, marquês de La Fayette, o vencedor da guerra da independência dos Estados Unidos, o conde de Mirabeau, dentre outros (CASTILHO, 2019).

Séculos depois, numa assembléia pública em Paris, Pierre Joseph Proudhon indaga a plateia pergunta: o que é a propriedade? Karl Marx que estava sentado na plateia respondeu com outras interrogações: "Propriedade? Mas que propriedade? Privada, propriedade burguesa?" A resposta desta interrogação feita por Proudhon da qual Karl Marx não respondeu é o objetivo deste trabalho. Economista e Sociólogos de tendência socialistas do século XX, influenciados pelos precursores do século XVIII que defendiam a propriedade em geral como propriedades sociais naturais, a exemplo 
do Mestre Pierre Joseph Proudhon em sua obra Qu'est ce que LA PROPRIÉTÉ, ou seja, "O que é a Propriedade", ao tempo de Karl Max que declarava a propriedade (imobiliária) privada de origem burguesa, tinha caráter capitalista, fundada no latifundiário medieval que originou a classe burguesa, hoje capitalista.

Percebam que o direito francês não conceituou a propriedade imobiliária, a mesma é considerada um direito sutilmente constitucional. É tutelada e albergada no Art. 17 da Declaração dos Direitos do Homem e do Cidadão. Como a propriedade é um direito inviolável e sagrado, ninguém dela pode ser privado, a não ser quando a necessidade pública legalmente comprovada o exigir evidentemente e sob condição de justa e prévia indenização.

Juridicamente é inviolável, não suportando o cidadão francês a privação deste direito. Somente mediante justa e prévia indenização. Em 16 de janeiro de 1982 foi concedido o valor constitucional da propriedade imobiliária, inserida por ligação aos princípios expressos pela Declaração dos Direitos do Homem e do Cidadão, salvaguardando o direito da propriedade imobiliária, designando-o como objetivos da sociedade política posicionando-a ao nível da liberdade, solidariedade e da fraternidade, garantindo-a a segurança e a resistência à opressão, (GUERRA, 2011).[2]

Na Itália, no âmbito do Direito Constitucional e no Direito Civil italiano, a propriedade imobiliária é estritamente a função social. Da qual ganha uma acepção definitiva e positiva pela parte do titular, em uma essência de cunho social e não do ponto de vista econômico. Trata-se duma materialização dos princípios fundamentais, em exclusivo: a dignidade da pessoa humana e o da justiça social. O proprietário da propriedade imobiliária, adentra em associação com outros cidadãos, acertadamente transportadores de acontecimentos juridicamente pertinentes, (GUERRA, 2011).

A Constituição da República Italiana, no título III, da parte das relações econômicas, inerente ao artigo 42, aqui, infra citado, em particular tradução:

A propriedade é pública ou privada. Os bens econômicos pertencem ao Estado, ou entidades, ou a particulares. A Propriedade é reconhecida e garantida pela lei, que determina as suas formas de aquisição, de posse 
e os limites, no intento de assegurar a sua função social e de torná-la acessível a todos. A propriedade privada pode ser, nos casos previstos pela lei e salvo indenização, expropriada por motivos de interesse geral. A lei estabelece as normas e os direitos da sucessão legítima e testamentária, e os direitos do Estado sobre as heranças.

A temática da função social da propriedade está profundamente conectada com o atual desuso da separação inflexível entre o direito público e o direito privado. Pareçase contraditório, o que de fato não o é, que a função social da propriedade italiana distinta por Barassi, na década de quarenta do século $\mathrm{XX}$, declarava que teria de ser prestigiada. A propriedade imobiliária é um poderio do qual o núcleo é localizado a meio de próprias demarcações, o dúbio conceito que outrora tinha mais de uma interpretação, torna-se um, numa fusão entre indivíduo e sociedade. Ao que parecia de entendimento contrário ou paradoxal, ao interpretar o artigo supramencionado. Se entrelaçaram, complementando-se em uma junção, formando um completo axioma, em pró do bem comum, em um difuso princípio coletivo, (BARASSI, 1943, apud GUERRA, 2011).[3]

Notem que o direito italiano não conceituou a propriedade imobiliária somente disse que poderia ser pública ou privada, respondendo a função social, que na falta desta poderá ser expropriada, ou seja, desapropriada, mediante indenização.[4]

Na Espanha, o artigo 33 da Constituição Espanhola, identifica o direito de propriedade da propriedade imobiliária privada, ou seja, o direito de detenção do bem, atribuindo status de direito fundamental constitucional. Na carta mátria espanhola o direito de propriedade imobiliária privada traz vários atributos subjetivos inerentes aos incisos 1 , 2 e 3 sobre a coisa, determinando um grupo de deveres e obrigações determinada em lei, respeitando os valores e interesses coletivos.

No Art. 33 da Constituição Espanhola, específico a parte dos direitos e deveres do cidadão, reconhece o direito de propriedade privada e da herança, assim como a função social destes direitos, dos quais serão definidos o seu conteúdo, de acordo com as leis que os regem. O bem e o direito privado é garantido pela lei, com exceção dada por interesse social de utilidade pública em pró do bem comum numa 
coletividade, mediante justa indenização correspondente o que estiver disposto em lei.

Tutelada sobre o manto teleológico do interesse social, que cada categoria de bem obedeça a sua teleologia. Necessária a referência a função social da propriedade imobiliária, compreendida como uma ordem constitucional, limitando-se externamente as intervenções administrativas por questões de utilidade e interesse público, além as agressões sociais, a exemplo do esbulho. A função social da propriedade imobiliária é um exercício como parte integrante de um direito-dever do proprietário, destarte, revelando a funcionalização do instituto ao exercer a determinação constitucional.[5]

Em Portugal, o Art. 1.305 do Código Civil português, declara que o proprietário da propriedade imobiliária tem o gozo, dada pela satisfação, contento e vontade integral absoluta, que exclui e elimina terceiros de modo privado e restrito. Que tem os direitos de utilizar ao emprego da aplicação na execução do exercício do desempenho de residir, um direito real à título oneroso ou gratuito, usando-se da coisa e utilizando para atender às suas próprias necessidades ou da família... juntamente com o processo ou efeito de fruir e de dispor, das coisas que Ihes pertencem, endo ditames legais e com o cumprimento das restrições por ela impostas.

Inverossímil ressaltar, que a propriedade imobiliária seja ilimitada em qualquer época da humanidade, a vida em sociedade exige contentamentos do qual arreda a personalidade absolutista antissocial, com tal característica, assim como no direito de Roma e no direito francês em regimes de governos de monarquias absolutistas a propriedade imobiliária nunca abandonou a busca dos interesses privados da família, do religioso e do público, com natureza limitada por exceção. O Código Civil português, o bem imóvel, vale dizer, a propriedade imobiliária não é objeto de definição legal no tocante ao conceito. (GUERRA, 2011).[6]

$\mathrm{Na}$ Alemanha, o Código Civil germano não definiu o conceito de propriedade imobiliária. O direito civil alemão traz a propriedade imobiliária em um rol entre os artigos 903 a 928. Iniciando-se com o poder de propriedade, dada pela faculdade do proprietário de coisa imóvel, expondo que o proprietário pode sempre desde que a lei 
ou direito de terceiros não se contrapor, podendo usufruir, desfrutar, dentre outras... de acordo com a sua volatilidade, e abolir demais pessoas de alguma invasão. Artigo 903 particularmente traduzido: "A menos que a lei ou os direitos de terceiros entrem em conflito com isso, o proprietário de uma coisa pode fazer com ela o que quiser e excluir outras pessoas de qualquer influência”.[7]

A limitação da propriedade na Alemanha no tocante ao espaço aéreo tem duas características onde esta esteja localizada, geralmente as cidades praianas como à exemplo de Boltenhagen, as propriedades imobiliárias sofrem uma limitação maior, em específico os imóveis construídos na orla marítima, não são muito altos! Parecendo demonstrar questões relacionadas às temperaturas ao tratar de corredores de ventos, enquanto cidades das quais não são litorâneas, por exemplo Frankfurt os prédios edilícios sofrem uma restrição menor podendo ser mais altos, como de fato são; não podendo o construtor ou proprietário construir a tal altura ou profundidade ao ponto de excluí-lo de intromissões de terceiros, quando este gerar danos a outro.

Diz que a propriedade imobiliária compreende ao subsolo até o espaço aéreo, passando pela superfície, não podendo abusar do direito de construir ao ponto de causar intromissões dadas pela altura ou profundidade (GUERRA, 2011).

Observem que o Código Civil Germânico trata: dos poderes do proprietário dados pelo direito de propriedade, do aprofundamento conexa responsabilidade civil, com a prevenção de não lesar pelo princípio do neminem laedere, da servidão, da limitação da propriedade, e por fim, da função social da propriedade, e não a conceituam.[8]

\section{CONSIDERAÇÕES FINAIS}

No tocante sobre a definição do conceito de propriedade imobiliária, no âmbito dos Direitos Reais, ao campo semântico da palavra, correspondendo o Direito Constitucional-Civil nacional e internacional, com a máxima vênia. O Professor Emérito da Faculdade de Direito da Universidade Federal da Bahia, Dr. Orlando Gomes, em sua obra titulada de Direitos Reais, no capítulo nove (9) conceitua propriedade como: "plena in re potesta", ou seja, diz que é a submissão de uma coisa 
segundo entendimento de Windscheid. No discorrer não define o que seja a propriedade imobiliária, somente trata da propriedade quanto aos: conteúdos, sujeitos, modalidades, caraterísticas (rural ou urbana) e finaliza com a função social.

A Professora Maria Helena Diniz, segue o mesmo entendimento do Professor Miguel Reale, que, por sua vez, segue o entendimento do direito romano. Ambos dizem que a propriedade, se traduz em um direito, que seja, de pessoa física, ou seja, de pessoa jurídica, das quais possuem inclusos nos marcos da norma jurídica. Sendo o uso, dado pelo costume de usar, praticando e utilizando do gozo, em uma dinâmica de desfruto e utilidade, ao ato de possuir por meio de deter coisa corpórea ou incorpórea, com o proveito de aproveitar, dispondo de plenitude e exclusividade, em consonância com limites e obrigações impostas pelo ordenamento jurídico, sempre pela ordem, em disposição regular de lei ou ordem constitucional. Podendo recuperar, reaver, retornar, repossuir ou readquirir, reivindicando de quem possua propriedade alheia de forma injusta, que contrarie a juridicidade, por meio de ação humana realizada ou omitida, proibida por um tipo legal, ausente justificativas legais ou supralegais, que caracterizem antijuridicidade, ou seja, um injusto que contrarie a justiça e a equidade. Note-se que os professores ressaltam faculdade do proprietário, e não o que seja a propriedade imobiliária!

O Art. 1.225 do Código Civil brasileiro de 2002, trata dos Direitos Reais da propriedade, no inciso I, e, não define o conceito de propriedade imobiliária. Entendese, em síntese, que parece ser o Direito de Propriedade um conceito amplo que traduz a propriedade, como a submissão da coisa à vontade do seu proprietário. A propriedade é a aquisição de um bem material ou imaterial, dada por uma relação jurídica de apropriação, que gera um poder de exercer sobre a coisa, um direito real que vincula a nossa personalidade sob as relações, seja como pessoa física ou jurídica, podendo usufruir do uso e dispor do bem. (Grifo nosso).

Nas constituições e códigos internacionais, após uma incessante investigação científica, não se encontrou evidências do conceito da propriedade imobiliária. De fato, o que se encontrou foi uma indagação feita por Pierre Joseph Proudhon, em uma obra intitulada Qu'est ce la propriété? Onde então indaga o que seja a propriedade, da qual 
responde que é o roubo! Não sabendo meramente responder a própria indagação (PROUDHON, 1840).

Com o devido respeito e com a responsabilidade do escrever, não gerando conflito de ideias, arrebatando o acrônimo e o provincianismo, do contexto histórico do qual os autores pesquisados estavam inseridos, para que não haja erros cronológicos, declaro que:

Diante do exposto, ao tocante a falta de definição do conceito de propriedade imobiliária, forçoso advogar, ao se fazer necessário para comunidade científica, o desabafo do pensamento jurídico! Ao responder sobre o que seja a propriedade imobiliária. É notório que o conceito de propriedade imobiliária, surja das características: implícitas, explícitas e intrínsecas ao objeto. Desta forma segue-se o resultado da incumbência deste Trabalho de Conclusão de Curso (TCC), (MBA) em Direito Imobiliário, o tão esperado conceito da propriedade imobiliária, aqui, in verbis, infra, descrito:

Propriedade Imobiliária em suma é um bem imóvel, correspondendo ao solo (superfície), ao subsolo e ao espaço aéreo, e em tudo em que nela the incorpore de forma natural ou artificial, considerando para efeitos legais, os direitos reais, sobre ela assegurados, não perdendo o seu caráter em construções apartadas do solo, mesmo que a sua unidade não tenha à raiz.

Via de regra é um bem de raiz, podendo ser: uma área de terra nua ou construída, habitável, corpórea, lícita, possível, determinada, pública ou privada. Edilícia ou horizontal, aferida metricamente, plena ou limitada, restrita, exclusiva, individual ou condominial, sucessível, multi, transmissível, escriturada, contrata, registrada, averbada, unitária, absoluta, perpétua, inscrita, continua, legal, disponível, usufrutuária, usucapida, adquirida por acessão, acrescida, prometida, comprometida, penhorada, hipotecada, servida, consignada, concedida, descrita, localizada, georreferenciada, confrontada e desmembrada, urbana ou rural, ambiental, econômica, familiar, cultural, assistencial de desportos, residencial, religiosa, industrial ou mercantil, coletiva, tributável, imune ou isenta, resolúvel, fiduciária, indenizada. 
Condicionada ao domínio de uma pessoa jurídica ou física, respondendo a sua função social da propriedade, conexa a função socioambiental, garantida expressamente da qual origina ao proprietário ou possuidor as faculdades de: gozo, uso, domínio útil, fruição e reivindicação, com efeitos propter rem e erga omnes.

\section{REFERÊNCIAS}

ALEMANHA. Bürgerliches Gesetzbuch. Berlin. 1881.

ALVES, J. C. M. Direito Romano. 14ª ed. Rio de Janeiro, Forense, 2008.

ASCENSÃO, J. de O. Direito Civil Reais. Editora Coimbra. 1ª ed. Coimbra. 2000.

AUGUSTO, E. A. A. Registro de Imóveis, Retificação de Registro e Georreferenciamento: Fundamento e Prática, Editora Saraiva, 1ª. ed. São Paulo, 2013.

BARASSI, L. La Proprietà nel Nuovo Codice Civile. Milano: Giuffrè, 1943.

BERTHE, M. M. Títulos Judiciais e o Registro Imobiliário. In: PÉREZ, Diego Selhane. São Paulo: IRIB, 2005.

BRASIL. Código Civil. Lei 10.406/2002. Brasília. Vade Mecum. 19. ed. São Paulo: Saraiva, 2019.

BRASIL. Constituição da República Federativa do Brasil. Vade Mecum. 19. ed. São Paulo: Saraiva, 2019.

BRASIL. Estatuto das Cidades Lei 10.257/2001. Brasília. 2001.

BRASIL. Lei de Registros Públicos. N. 6.015/1973. Brasília. 1973.

CASTILHO, R. Direitos Humanos. $6^{\underline{a}}$ ed. São Paulo. Saraiva. 2019. p. 93.

DINIZ, M. H. Dicionário Jurídico Universitário. Editora Revista dos Tribunais. São Paulo, 2012. p. 477. 
ESPANHA, Constitución Española. Madri. 1978.

FILME: O Jovem Karl Marx. YouTbe.com//watch?v=2M5vo2n6G7Y\&t=1297s). 2020.

FRANÇA, La Constitution Nationale de France. Parre. 1791.

GOMES, O. Direitos Reais, editora Forense, 21르 edição, Rio de Janeiro, 2012.

GUERRA, A. A Propriedade Imobiliária na Legalidade Constitucional. Editora Quartier Latin. São Paulo, 2011, p. 28-29-30-34-35.

ITÁLIA, Costituzione Della Repubblica Italiana. Roma. 1947.

LANVERSIN, J. de. La propriété, une nouvelle règle du jeu? Presses Universitaires, Traité de Droit Constitutionnel, Paris, França,1975.

PORTUGAL, Código Civil Portuguez. Lisboa. 1867.

PROUDHON, De P. J. Qu'est ce la Propriété. Editora Estampa, Lisboa. 1975, p. 11.

PUGLIATTI, S. La Proprietà nel Nuovo Diritto. Milano; Giuffrè, 1964.

VARELA, J. M. A. Direito das Obrigações. Coimbra: Almedina, 2003.

VENOSA, S. de S. Direitos Reais, 12ª edição, editora Atlas, São Paulo. 2012.

\section{APÊNDICE - REFERÊNCIAS DE NOTA DE RODAPÉ}

2. Filme: O Jovem Karl Marx, YouTbe.com/ /watch?v=2M5vo2n6G7Y\&t=1297s.p.

3. Article 17 - La propriété étant un droit inviolable et sacré, nul ne peut être privé, sauf si le besoin public légalement prouvé l'exige évidemment et sous condition d'une compensation juste et préalable.

4. Costituzione Della República Italiana. Art 42. La proprietà è pubblica o privata. I beni economici appartengono allo Stato, ad enti o a privati . La proprietà privata è 
riconosciuta e garantita dalla legge, che ne determina i modi acquisto, di godimento e i limiti allo scopo di assicurare la funzione sociale e di renderla accessibile a tutti. La proprietà privata può essere, nei casi preveduti dalla legge, e salvo indennizzo, espropriata per motivi di interesse generale. La legge stabilisce le norme ed i limiti della successione legittima e testamentaria e i diritto dello Stato sulle eredità.

\section{Artículo 33.}

6. Art 1.305 - O proprietário goza de modo pleno e exclusivo dos direitos de uso, fruição e disposição das coisas que the pertencem, dentro dos limites da lei e com observância das restrições por ela impostas.

7. 1. Se reconoce el derecho a la propiedad privada y a la herencia.

2. La función social de estos derechos delimitará su contenido, de acuerdo con las leyes

3. Nadie podrá ser privado de sus bienes y derechos sino por causa justificada de utilidad pública o interés social, mediante la correspondiente indemnización y de conformidad con lo dispuesto por las leyes.

\section{8. §903 Befugnisse des Eigentümers}

Der Eigentümer einer sache kann, soweit nicht das Gesetz oder Rechte Dritter entgegenstehen, mit der sache nach Belieben verfahren und andere von jeder Einwirkung ausschließen.

\section{§ 905 Begrenzung des Eigentums}

Das Recht des Eigentümers eines Grundstücks erstreckt sich auf den Raum über der Oberfläche und auf den Erdkörper unter der Oberfläche.

Enviado: Julho, 202.

Aprovado: Dezembro, 2020. 